\title{
Study on the education mode of the Industry- University-Institute Cooperation for Civil Engineering Specialty in Local Colleges
}

\author{
Huang Ying \\ College of Architecture and Civil Engineering, Jiangxi \\ Science \& Technology Normal University, Nanchang, \\ China 330013 \\ Huangying7871@163.com
}

\author{
Guo Pan \\ Academic Affairs Office, Jiangxi Science \& Technology \\ Normal University, Nanchang, China 330013 \\ 254366147@qq.com
}

\begin{abstract}
- in this paper the history, present situation and advantage of the industry-university-institute cooperation were elaborated. The necessity of implementing the industryuniversity-institute cooperation in local colleges and universities was presented based on State Planning Outline for Medium and long-term education reform and development and local development. Difficulties local colleges and Universities faced in the process of implementing the education mode of the industryuniversity-institute cooperation were analyzed by research. To solve the problems the specific improvement measures of the industry-university-institute cooperation based on the civil engineering specialty in local colleges and universities were put forward. The advice on specialty setting, practical teaching link, teacher team construction and the class hour proportion of industry-university-institute was given, which carried out the useful discussion for further development of education reform in local colleges and universities and their own development of local colleges and universities to better serve the local.
\end{abstract}

Keywords-the education mode of the industry-universityinstitute cooperation; local characteristics; practical teaching link; specific measure

\section{THE NECESSITY OF CARRYING OUT THE EDUCATION MODE OF THE INDUSTRY-UNIVERSITY-INSTITUTE COOPERATION IN LOCAL COLLEGES}

The education mode of the industry-university-institute cooperation was initiated by Hermann Schneider-Dean of the Faculty of engineering, University of Cincinnati in 1906 [1]. And the scientific research program for undergraduates was carried out at Massachusetts Institute of Technology. Accordingly, the mode of the industry-university-institute cooperation was adopted to train college students in various forms at Germany and the United Kingdom. Practice has proved that the education mode of the industry-universityinstitute cooperation is the internationally recognized best way to cultivate innovative talents.

The education mode of the industry-university-institute cooperation was the education mode that can take advantage of a variety of different learning environment, teaching resources and their respective advantages in terms of talents training of the industry-university-institute and can combine school education based on classroom instruction with practice and scientific research [2]. It can solve the disjunction of school education and social need, can narrow the gap between school education and social needs for talent, and can enhance the students' social competence.

Study and formulate work of State Planning Outline for Medium and long-term education reform and development (2010-2020) [3] began in August, 2008. On the basis of indepth research, widely soliciting opinions and fully evaluation by experts the outline was formally released on July 29, 2010. The outline elaborates the ten major themes and thirty-six subtopics of our country education reform and development over the next 10 years. And the outline points out the direction, plans the education blueprint and puts forward the guiding opinions for the next 10 years. The Outline clearly pointed out that we must support students to participate in scientific research, strengthen the practice teaching links, promote the entrepreneurship education and build the new mechanism of united talents training of universities with scientific research institutions, trades and enterprises about higher education. With the rapid development of higher education in China the higher education altered from elite education period to mass education period. And the training mode and training goal of higher education also changed accordingly. Education [4], in a broad sense, is the activity to enhance peoples' knowledge and skills, influence peoples' ideology and morality and strengthen people's physical fitness. Education, in a narrow sense, is the school education that according to the requirements of certain social or class, following the development rules of the younger generation of physical and mental, purposefully, designedly, systematically guides the educatees acquire knowledge skills, cultivates ideology and moral character and develops intelligence. The purpose of education is to enable the educatees to acquire knowledge and skills. The education mode of the industry-university-institute cooperation not only makes students obtain knowledge through university-institute cooperation mode, also enables students to acquire skills through industry-university cooperation mode. So the education mode of the industry- university-institute cooperation can realize the purpose of education in a more comprehensive way. The foundation of the survival and development of local institutions lies in the localization idea- 
basing on the local and serving local economy. Local college aims to provide theoretical and technical support to local economic and social development and culture the practical and comprehensive technical talents. The education mode of the industry-university-institute cooperation makes full use of the educational environment and resources of enterprises and combines theoretical knowledge with production practices, which help to develop knowledge and skills for students. The education mode of the industry-university-institute cooperation takes the market as the guidance so it can cultivate applied talents and research talents for the development of local economy in zero-distance. It can provide students with the practical and innovative stages. It also can make talent cultivation in two kinds of educational environment-school and society and make the education goal clearer.

Therefore, it is necessary for local colleges and universities to adopt the education mode of the industry-university-institute cooperation to train graduates with more social adaptability.

\section{DifFICULTIES LOCAL COLLEGES AND UNIVERSITIES FACED IN THE PROCESS OF IMPLEMENTING THE EDUCATION MODE OF THE INDUSTRY-UNIVERSITY-INSTITUTE COOPERATION}

\section{A. The government's policy level}

At present the education mode of the industry-universityinstitute cooperation take colleges and Universities as the lead. Colleges and universities are trying to seek cooperation of enterprise and support of government. In China the government supports the implementation of education mode of the industryuniversity-institute cooperation in the University, but there are no systematic policies. Because of lack of systematic policies and regulations to support and guide, the education mode of the industry-university-institute cooperation has no continuity, persistence, macro and comprehensive. The development process of the education mode of the industry-universityinstitute cooperation in the United States, Germany, Britain and other countries shows that government play an important role in organizing and guiding it to carry out in-depth.

\section{B. Enterprise ideology}

The economic development is uneven in China and the proportion of private economy is large in some areas. The economic base of private enterprise is relatively weak and the survival and development pressure is large. To private enterprise the economic benefit is the first factor. The private enterprise's responsibility for talents cultivation is poor. There is no consciousness of private enterprise to play the advantage for training talents. In ideology, the enterprise doesn't agree with its important role in the talents cultivation. At present the enterprise in the process of implementing the education mode of the industry-university-institute cooperation has not gotten substantial benefits. So the enterprise lacked enthusiasm. Lack of active participation of enterprise, it is difficult to carry out the education mode of the industry-university-institute cooperation. Then the superiority of the education mode of the industry-university-institute cooperation is difficult to fully play.

\section{No specific implementation methods of the education mode of the industry-university-institute cooperation}

On the level of universities, the advantage of the education mode of the industry-university- institute cooperation in the talents cultivation has been demonstrated. So it has cognizance in a certain degree. However, at the present stage the education mode of the industry-university- institute cooperation is in the exploratory stage. Many colleges and universities developed some implementation measures according to their own characteristics. But now there is no systematic, specific implementation measure for the education mode of the industry-university-institute cooperation. The education mode of the industry-university- institute cooperation includes three teaching system: the theory teaching system, practice teaching system and scientific research and innovation teaching system. The theory teaching system has been implemented in colleges and universities, so it is relatively perfect. The practice teaching system is dominated by enterprises. And it is the new teaching system. The teaching content, teaching methods, teaching means and assessment methods are very different with those of the theory teaching system. They have variability and uniqueness. There is no unified mode for the formulation of the specific implementation methods. So the specific implementation methods of practice teaching system were deficient. While scientific and rational evaluation system of practice links is the most lack parts in specific implementation measures. The formulation of the specific implementation methods of scientific research and innovation teaching system can learn from postgraduate training mode. But according to the job market requirements for the undergraduates it still needs to be adjusted and improved.

III. THE SPECIFIC IMPLEMENTATION MEASURES OF THE EDUCATION MODE OF THE INDUSTRY-UNIVERSITY-INSTITUTE

COOPERATION IN LOCAL COLLEGES AND UNIVERSITIES OF Civil EngineERING Specialty

\section{A. Local characteristics}

Local colleges and universities aim to service local and meet the requirement of local economic development. So according to local characteristics developing the education mode of the industry-university-institute cooperation with local characteristics is the breakthrough of higher education reform. Take Jiangxi province for example, it is a mountainous and hilly area. Under the current background of rapid development of urbanization, urbanization construction in a mountainous and hilly area is a breakthrough point of combination talents training with local characteristics in Jiangxi colleges and Universities of Civil Engineering Specialty. Jiangxi has a good natural environment and ecological environment. Combined with the sustainable development strategy, according to local conditions, green building is another breakthrough point. To strengthen the cooperation between local universities and related departments is an effective way to promote the construction of the education mode of the Industry-UniversityInstitute Cooperation with local characteristics in Jiangxi colleges and Universities of Civil Engineering Specialty. Generally speaking, combined the local environmental characteristics, the current situation of the local economic 
development, the local competitive industries with the educational ideas, the local colleges and universities must seek for the specific implementation measures of education mode of the industry-university-institute cooperation fitted with their own talents training goal by themselves.

\section{B. Production, research diverge and Training scheme is well tailored according to students' ability and job-hunting Intention}

The higher education altered from elite education period to mass education period in China. So the mode of higher education must be correspondingly adjusted. After freshman year, students can select the application oriented talent training plan or the research oriented talent training plan according to their own learning situation and job-hunting Intention. Then students can enter into the corresponding training mode and training programme according to the previous choice. Now the Excellence engineer education plan is the highlight of the application oriented talent training plan. To improve the students' interest in profession learning and enhance students' skills we must actively encourage civil engineering students to participate in professional competition in the process of teaching, such as mathematical modeling, Zanesville contest, 'glodon' campus BIM skills competitions. At the same time it is also a good way to enhance students' skill to make full use of social resources and encourage civil engineering students to participate in professional skills training course. It is also a good way to enhance students' skill that the contents related National Registered Professional Engineer exam are implanted in classroom teaching and curriculum assessment. On the other hand, students' research and innovation projects can train students' scientific research ability. The open experimental project can not only cultivate the students' practical ability, but also can cultivate students' scientific research ability. They are the effective ways to realize the education mode of the industry-university-institute cooperation. To know the subject frontier knowledge and development trends, enhance the academic sensitivity and improve the scientific research literacy the students must actively participate in academic exchanges.

\section{The education mode of the industry-university-institute cooperation must be supported by the government policy}

The development and perfection of the education mode of the Industry-University- Institute Cooperation must be supported by government. The success of the education mode of the industry-university-institute cooperation in America depended on government's support [5]. The government urged multilevel and multilateral cooperation between enterprises and university to deepen and guarantee funds energetic by formulating policies. In Japan the education mode of the industry-university-institute cooperation emphasizes on the government action. Government involvement urged the enterprises to provide more projects and funds to universities. The government provides legal protection for the education mode of the industry-university-institute cooperation by formulating the corresponding policies. And the government's function of macro control is helpful to establish a sound service system for the education mode of the industry-university- institute cooperation and build a good platform for cooperation between enterprises and university. Based on system, the longterm mechanism of the education mode of the IndustryUniversity- Institute Cooperation must be built.

\section{Play a role in the cultivation of talents, and cultivate the sense of responsibility of the enterprises for the talents cultivation}

The business community generally believed that the longterm goal of enterprise development is to introduce the young with good training and familiar with their enterprise culture in Germany [6]. The Japanese model of the education mode of the Industry-University- Institute Cooperation emphasized that the industry and the university had the same responsibility of the talent training. To improve the core competitiveness of the enterprise the enterprise must do well in talent training. The enterprise must take their responsibility for talent cultivation. On the other hand, the driving force of enterprises to participate in the training of talents is to establish a rational talents cultivation mode of the industry-university-institute cooperation which can create the win-win situation of enterprises and University. The enterprise can provide direction for personnel training in Colleges and universities. At the same time the enterprise can also provide students stage to show their talents. The ultimate goal of talent training in colleges and universities is to serve the enterprise. The enterprises have an important role in the talent training, which the enterprises must fully understand. So the enterprises must play a very important role in the talent training.

\section{THE THINKING OF THE EDUCATION MODE OF THE INDUSTRY-UNIVERSITY-INSTITUTE COOPERATION IN LOCAL COLLEGES AND UNIVERSITIES}

\section{A. Prospectiveness of specialty setting}

The local colleges and Universities must take full account of the market demand when setting specialty. The specialty setting must be marked oriented, meet the needs of enterprise development and make enterprise actively participate in the education mode of the industry-university-institute cooperation. The talent training needs some time, so the local colleges and universities should be prospective and predictive in the specialty setting. Professional setting must consider the enterprise needs of the long development and the long-term personnel training reserves, so as to enhance the enterprises enthusiasm to participate in the education mode of the industry-university-institute cooperation and improve compactness of university-enterprise cooperation.

\section{B. Pay attention to practical teaching link}

The education mode of the industry-university-institute cooperation is the mode that the university and enterprise jointly foster and supervise students in essence. To some extent practice teaching is very flexible. The effective means to urge practice teaching is to standardize the practice teaching management, ensure practice teaching quality and develop scientific reasonable practice teaching evaluation system. At present the key work of practical teaching link is to build the reasonable implementation methods. The one of the specific 
implementation methods is to strengthen practice base construction, make full use of social resources, let the student really deep into enterprise production links and participate in production activities of enterprises by post fixation. The second is to reasonably adjust teaching plan, break the boundary of the term and holidays and let students take full advantage of the holidays to carry out practice teaching. Another is to give full play to students' initiative, combine scattered practice teaching with concentrated practice teaching and combine the short term practice with tracking practice.

\section{Teacher team construction of the education mode of the industry-university-institute cooperation}

The multidirectional flows employment mechanism of engineer, technician and University Teachers must be built to enhance communication and form Complementary. On the one hand, the engineers were invited into university teachers which can improve engineers' theoretical level. On the other hand, university teachers are employed in enterprise to improve the professional skills and rich practical experience. Buildup of the double-professionally-titled teachers can enhance the vitality of the education mode of the industry-university-institute cooperation. University teachers must have three functions: teaching, scientific research, social services. On the basis of the completion of the teaching work, the university teachers should actively carry out technological innovation research and obtain industry qualification certification.

\section{Develop a reasonable class hour proportion of industry- university-institute}

Take the students' employment situation as the guidance, according to university orientation in the local economy and industry development, it is necessary to formulate the reasonable talent training scheme and scientifically allocate hour proportion of industry-university-institute. Based on the credit system, students can combine with teaching content come from different teaching link according to their learning ability and learning situation.

\section{CONCLUSION}

The necessity of carrying out the education mode of the industry-university-institute cooperation in Local Colleges was proved by analyzed educational purposes and the mission of university. At the same time difficulties local colleges and universities faced in the process of implementing the education mode of the industry-university-institute cooperation were present. At last to solve the problems the specific measures and suggestions of the education mode of the industry-universityinstitute cooperation in local colleges was put forward. This paper provided theoretical support for local colleges and universities to implement smoothly the education mode of the industry-university-institute cooperation.

\section{ACKNOWLEDGMENT}

The authors would like to express their appreciation to Jiangxi Science \& Technology Normal University. The research works belong to one part of the projects (JGZD-1417-10) which are finically supported by teaching reform project of Jiangxi science \& technology normal university.

\section{REFERENCES}

[1] Zeng Wei, You Daming, Liu Aidong. The research and practice on culitivating students' innovative ability by co-operative education-Taking C University as an example[J].University education science, 2012,135(5):63-70

[2] XIE Hua-yan, WANG Xiao-ning, ZHAO Xiao-lin, et al. Practical teaching construction based on university-industry cooperation[J]. Journal of Lanzhou university of arts and science (natural sciences), 2015,29(1):105-108

[3] Medium and Long-term Education Reform and Development(20102020)[M]. Beijing: People's Press, 2010, 7

[4] Whitehead. The aims of education[M].Shanghai: Wenhui press, 2012

[5] Du shuang, Research on the mode of cooperative education in local institutions[J]. Journal of Changchun University, 2010, 20(12):9394,116

[6] Chen Jingrong. The development pattern and enlightenment of producing learning researching cooperative education in developed countries[J]. Journal of Yangtze University (Social Sciences), 2007, 30(5):128-131 